\title{
Effects of hypophysectomy and of LH administration on luteal phase plasma progesterone levels in the beagle bitch
}

\author{
P. Concannon \\ Department of Physical Biology, New York State College of Veterinary Medicine, \\ Cornell University, Ithaca, New York, 14853, U.S.A.
}

\begin{abstract}
Summary. Luteal-phase progesterone levels in 5 beagle bitches fell to $0.3-0.4 \mathrm{ng} / \mathrm{ml}$ within 3-17 days after hypophysectomies on Day 10-50 of the cycle. Plasma progesterone in 6 bitches increased $(P<0.01)$ within $3 \mathrm{~h}$ after $\mathrm{LH}(100 \mu \mathrm{g} / \mathrm{kg})$ injection between Days 35 and 55 of the cycle. Normal luteal function in the bitch appears to require continuous pituitary trophic support perhaps involving LH.
\end{abstract}

\section{Introduction}

Ovulation and formation of corpora lutea occur spontaneously in the dog. Profiles of circulating progesterone levels associated with preovulatory luteinization and with luteal function during pregnant and non-pregnant cycles have been reported (Smith \& McDonald, 1974; Concannon, Hansel \& Visek, 1975; Hadley, 1975a, b; Concannon, Powers, Holder \& Hansel, 1977a). Luteinization appears to be a response to the preovulatory surge in LH and the initial increase in progesterone occurs concomitant with the LH surge (Concannon, Hansel \& McEntee, 1977b). However, information on mechanisms controlling progesterone secretion throughout the luteal phase in bitches is limited, particularly in regard to any requirement for pituitary luteotrophic support.

The mean duration of luteal function, based on the presence of plasma progesterone levels above $1 \mathrm{ng} / \mathrm{ml}$, is longer in non-pregnant bitches ( 84 days) than in pregnant bitches (65 days); progesterone levels fall dramatically at parturition. Secondary increases in progesterone following implantation suggest that canine corpora lutea may be responsive to a placental gonadotrophin (Smith \& McDonald, 1974; Concannon et al., 1975, 1977a). Hypophysectomy at 5-7 weeks of gestation results in abortion (Aschner, 1912; Houssay, 1935; Votquenne, 1936). Hysterectomy does not appear to prolong luteal lifespan (unpublished observations) but has been reported to shorten it (Hadley, 1975c). Prostaglandin F-2 $\alpha$ is luteolytic in pregnant and non-pregnant bitches (Concannon \& Hansel, 1977).

Luteal function in several species has been shown to be dependent on continued luteotrophic support from the pituitary and/or responsive to pituitary hormone administration. The present paper details changes in plasma progesterone after hypophysectomy or LH administration during the luteal phase of non-pregnant beagle bitches.

\section{Materials and Methods}

\section{Animals and experiments}

The 2-4-year-old beagle bitches, animal maintenance procedures and methods for detection of oestrus, collection of blood and preparation of plasma were as previously described (Concannon et al., 1975, 1977a). 
Five bitches were hypophysectomized during the luteal phase of the cycle, on Day 10, 35, 40,45 or 50 after the onset of oestrus, and one bitch was subjected to sham-hypophysectomy on Day 25. The transbuccal approach and surgical procedures used were as described by Markowitz \& Archibald (1956). Progesterone was assayed in plasma samples collected at various intervals during the luteal phase and daily for several days before and after surgery. Recoveries from surgery were uneventful. Before subsequent steroid hormone treatments all bitches were maintained without supportive therapy for a minimum of 3 weeks. The bitches hypophysectomized on Days 10 and 35 were maintained without supportive therapy for 10 months during which both became obese, lethargic and myxoedematous.

Subsequent post-mortem examinations revealed no grossly visible pituitary remnants except for the retention of the pars nervosa in the animal hypophysectomized on Day 40. Microscopic examinations of multiple sections of the hypothalamus and of the sella turcica revealed a small remnant of anterior pituitary, in addition to a portion of pars intermedia and/or pars nervosa, in each bitch except that hypophysectomized on Day 35. Each of the 4 remnants of anterior pituitary was estimated to be less than $2 \%$ of the total lobe.

Other bitches received a single i.m. injection $(1.0 \mathrm{ml})$ of bovine $\mathrm{LH}(\mathrm{N}=6)$ or saline $(\mathrm{N}=5)$ between 35 and 55 days after the onset of oestrus. Progesterone was assayed in plasma collected at $-96,-24,-4,0,1.5,3,6$ and $10 \mathrm{~h}$ after the $\mathrm{LH}(\mathrm{NIH}-\mathrm{LH}-\mathrm{B} 5,100 \mu \mathrm{g} / \mathrm{kg})$ or saline $(9 \mathrm{~g}$ $\mathrm{NaCl} / \mathrm{l}$ ) injections. Progesterone levels were expressed as a percentage of the preinjection levels and differences between means due to treatment were determined by Student's $t$ test.

\section{Progesterone assay}

Plasma progesterone concentrations were determined in quadruplicate using methods of extraction and radioimmunoassay previously reported in detail (Concannon et al., 1977a). The antiserum to progesterone was specific (deVilla, Roberts, Wiest, Mikhail \& Flickinger, 1972). The assay was sensitive to $30 \mathrm{pg} /$ tube $(120 \mathrm{pg} / \mathrm{ml})$ and had a mean within-assay coefficient of

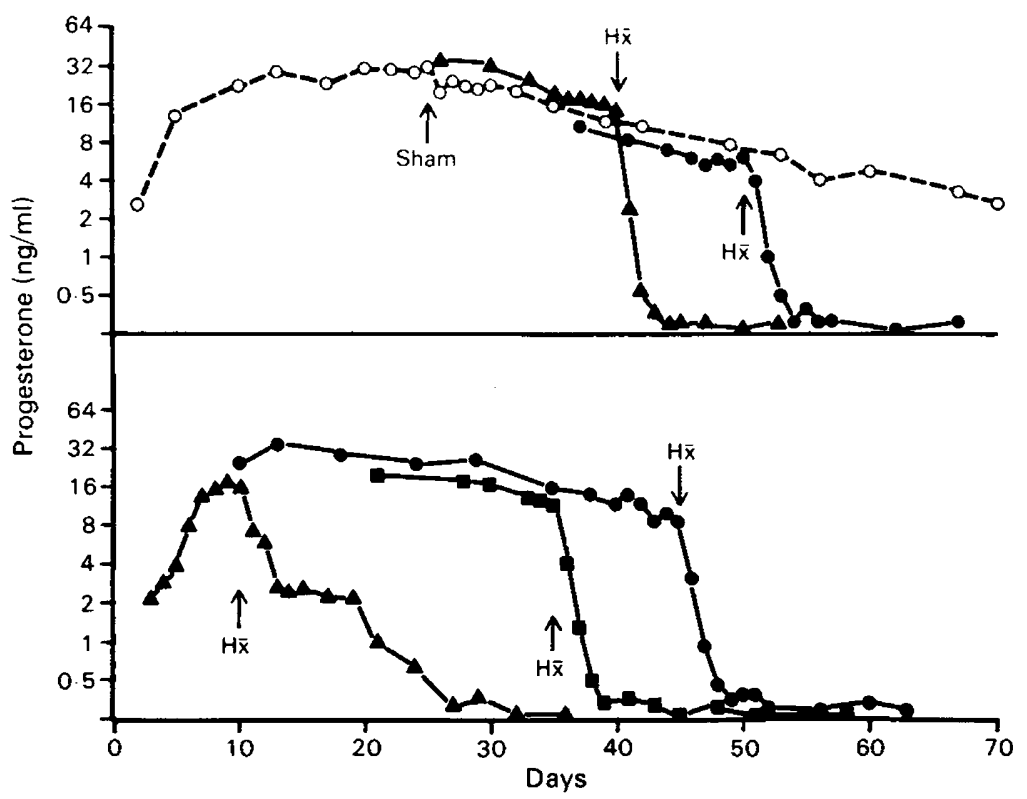

Text-fig. 1. Plasma progesterone levels in individual beagle bitches hypophysectomized (solid symbols) or sham-hypophysectomized $(O)$ between Days 10 and 50 after the onset of oestrus. Note log scale on ordinate. 
variation of $9 \%$ based on all samples assayed. The mean between-assay coefficient of variation was $14 \%$ for plasma pools of 1,5 and $25 \mathrm{ng} / \mathrm{ml}$ run in each assay. Values reported were not corrected for extraction efficiency $(91 \pm 1 \%$ ) or for the $200-300 \mathrm{pg} / \mathrm{ml}$ assayed in plasma of ovariectomized bitches.

\section{Results}

Plasma progesterone concentrations in the hypophysectomized bitches are shown in Text-fig. 1 . Progesterone decreased dramatically after hypophysectomy, falling to basal levels $(0.3-0.4$ $\mathrm{ng} / \mathrm{ml}$ ) within 3-4 days when the operations were performed between Days 35 and 55 of the cycle. Similar basal levels were not reached until 17 days after the hypophysectomy performed on Day 10. Except for a transient decline in progesterone on the day after surgery, luteal function did not appear to be altered in the sham-operated control bitch.

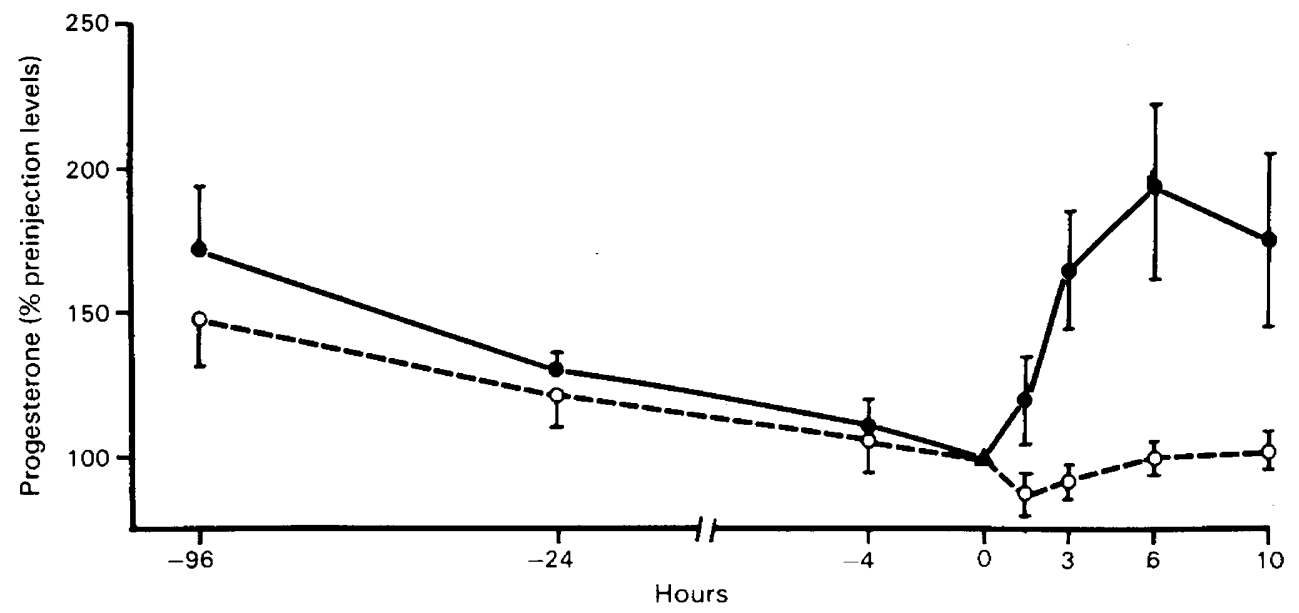

Text-fig. 2. Mean ( \pm s.e.m.) changes in plasma progesterone concentrations in beagle bitches injected at $0 \mathrm{~h}$ with $\mathrm{LH}(0, \mathrm{~N}=6)$ or saline $(0, N=5)$ between Days 35 and 55 of the cycle. Preinjection progesterone levels $(\triangle)$ were $12.8 \pm 4.1$ and $14.5 \pm 5.1 \mathrm{ng} / \mathrm{ml}$, respectively.

Progesterone levels just before injection of $\mathrm{LH}$ or saline between Day 35 and 55 of the cycle were variable, ranging from 2.0 to $30.9 \mathrm{ng} / \mathrm{ml}$ (average $13.6 \pm 3.1$ (s.e.m.) $\mathrm{ng} / \mathrm{ml}$ ). Mean progesterone concentrations (as a \% of preinjection levels) were higher $(P<0.05-0.01)$ in $\mathrm{LH}-$ treated bitches than in controls at $1.5,3,6$ and $10 \mathrm{~h}$ after injection (Text-fig. 2).

\section{Discussion}

The declines in progesterone following complete or nearly complete ablation of the pituitary in this study indicate that luteal sufficiency in the non-pregnant bitch is chronically dependent on pituitary secretion of luteotrophic hormone(s). A longer time was required for plasma progesterone to reach basal levels in the bitch hypophysectomized on Day 10 than in the other bitches: Further study will be needed to determine whether the difference was due to an ability of younger corpora lutea to function longer than older corpora lutea in the absence of adequate luteotrophic support. The difference may have been due to a difference in the amounts or secretory capacity of microscopic remnants of anterior pituitary that was not evident from the post-mortem examination of pituitary remnants.

The nature of the luteotrophic requirement appears to vary considerably among different 
species studied (see Savard, 1973; Hilliard, 1973; Hansel, Concannon \& Lukaszewska, 1973; Knobil, 1973). The increases in progesterone elicited by exogenous LH in the present study provide at least indirect evidence that $\mathrm{LH}$ may be part of the luteotrophic hormone requirement for normal luteal function in the bitch.

This work was supported in part by NIH Contract No. 72-2725. Technical assistance was provided by $\mathrm{Mr} \mathrm{R}$. Cowan and Mr M. Lanieu.

\section{References}

Aschner, B. (1912) Uber die Funktion der Hypophyse. Pflugers Arch. ges. Physiol. 146, 1-146.

Concannon, P.W. \& Hansel, W. (1977) Prostaglandin $F_{2 a}$ induced luteolysis, hypothermia and abortions in Beagle bitches. Prostaglandins 13, 533-542.

Concannon, P., Hansel, W. \& Visek, W. (1975) The ovarian cycle of the bitch: plasma estrogen, LH and progesterone. Biol. Reprod. 13, 112-121.

Concannon, P.W., Powers, M.E., Holder, W. \& Hansel, W. (1977a) Pregnancy and parturition in the bitch. Biol. Reprod. 16, 517-526.

Concannon, P., Hansel, W. \& McEntee, K. (1977b) Changes in $\mathrm{LH}$, progesterone and sexual behavior associated with preovulatory luteinization in the bitch. Biol. Reprod. 17, 604-613.

deVilla, G.O., Roberts, K., Wiest, W.G., Mikhail, G. \& Flickinger, G. (1972) A specific radioimmunoassay of plasma progesterone. J. clin. Endocr. Metab. 35, $458-460$.

Hadley, J.C. (1975a) Total unconjugated oestrogen and progesterone concentrations in peripheral blood during the oestrous cycle of the dog. J. Reprod. Fert. 44, 445-451.

Hadley, J.C. (1975b) Total unconjugated oestrogen and progesterone concentrations in peripheral blood during pregnancy in the dog. $J$. Reprod. Fert. 44, 453-460.
Hadley, J.C. (1975c) The effect of serial uterine biopsies and hysterectomy on peripheral blood levels of total unconjugated oestrogen and progesterone in the bitch. J. Reprod. Fert. 45, 389-393.

Hansel, W., Concannon, P.W. \& Lukaszewska, J.H. (1973) Corpora lutea of the large domestic animals. Biol. Reprod. 8, 222-245.

Hilliard, J. (1973) Corpus luteum function in guinea pigs, hamsters, rats, mice and rabbits. Biol. Reprod. 8, 203-221.

Houssay, B.-A. (1935) Action de l'hypophysectomie sur la grossesse et la sécrétion lactée chez la chienne. $C$. $r$. Séanc. Soc. Biol. 120, 496-497.

Knobil, E. (1973) On the regulation of the primate corpus luteum. Biol. Reprod. 8, 246-258.

Markowitz, J. \& Archibald, J. (1956) Transbuccal hypophysectomy in the dog. Canad. J. Biochem. Physiol. 34, 422-428.

Savard, K. (1973) The biochemistry of the corpus luteum. Biol. Reprod. 8, 183-202.

Smith, M.S. \& McDonald, L.E. (1974) Serum levels of luteinizing hormone and progesterone during the estrous cycle, pseudopregnancy and pregnancy in the dog. Endocrinology 94, 404-412.

Votquenne, M. (1936) Relations physiologique hormonales au cours de la gestation chez la chienne. Hypophysectomie. C. r. Séanc. Soc. Biol. 122, 9193.

Received 20 June 1979 